\title{
AMELIORATIVE EFFECTS OF GRAPE SEED OIL ON CHROMIUM-INDUCED NEPHROTOXICITY AND OXIDATIVE STRESS IN RATS
}

\author{
Sahar Hassan Orabi ${ }^{1 *}$, Sherif Mohamed Shawky² \\ ${ }^{1}$ Department of Biochemistry and Chemistry of Nutrition, Faculty of Veterinary Medicine, ${ }^{2}$ Department of Physiology, Faculty of Veterinary \\ Medicine, University of Sadat City, Egypt \\ *Corresponding author, E-mail: saher977@yahoo.com
}

\begin{abstract}
The current study focused on investigating the renoprotective effects of grape seed oil (GSO) against hexavalent chromium ( $\mathrm{Cr}(\mathrm{VI})$ )-induced nephrotoxicity. A total of 40 male rats were randomly divided into four groups: group I served as the control group, group II received $1000 \mathrm{mg} / \mathrm{L}$ potassium dichromate $(353.5 \mathrm{mg} / \mathrm{L} \mathrm{Cr}(\mathrm{VI})$ ) in drinking water for 12 weeks, group III received $3.7 \mathrm{~g} / \mathrm{kg}$ body weight/day GSO orally for 12 weeks, and group IV received GSO together with potassium dichromate for 12 weeks. $\mathrm{Cr}(\mathrm{VI})$ significantly increased serum levels of urea, creatinine, potassium and glucose. In addition, $\mathrm{Cr}(\mathrm{VI})$ increased MDA levels and induced renal tissue damage and DNA damage. On the other hand, $\mathrm{Cr}(\mathrm{VI})$ decreased serum levels of sodium and antioxidant defence system [reduced glutathione (GSH) and catalase (CAT)]. However, treatment with GSO prevented elevation levels of serum urea, creatinine, potassium and glucose. In addition, GSO enhanced sodium level, renal tissue antioxidant defense system due to its curative effect ameliorated particularly oxidative stress, renal tissue and DNA damage. In conclusion, these results demonstrate that GSO is a promising nephroprotective agent against $\mathrm{Cr}(\mathrm{VI})$-induced nephrotoxicity.
\end{abstract}

Key words: grape seed oil; hexavalent chromium; nephrotoxicity; DNA damage

\section{Introduction}

Grapes have high phenolic and essential fatty acid contents. Most phenolics are found in the seeds. Grape seed oil (GSO) contains large amounts of phenolic compounds such as epicatechin, gallic acid, catechin, procyanidins, and resveratrol and small amounts of hydroxytyrosol and melatonin (1-2).

GSO has high unsaturated fatty acids content that accounts for more than $89 \%$ of the total oil composition, containing $75 \%$ linoleic acid, $6 \%$ palmitic acid, $15 \%$ oleic acid, $1 \%$ linolenic acid and $3 \%$ stearic acid (3). Additionally, GSO has very

Received:2October 2019

Accepted for publication: 7 May 2020 high levels of antioxidants including vitamin $\mathrm{E}$ (120 mg/100 g), and phytosterols that can have an anti-atherosclerotic effect (4). Resveratrol (transresveratrol; trans-3,5,40-trihydroxystilbene) is a polyphenol in the stilbene family that is found at relatively high levels in grapes (5). The antioxidant property of GSO has been proposed to underlie its renoprotective activity (6-7).

GSO exerts important effects such as reducing platelet aggregation, normalizing lesions resulting from obesity and diabetes, and preventing hypertension caused by excess sodium (8).

GSO also exerts protective effects against acute liver injury induced by $\mathrm{CCl}_{4}$ due to its powerful antioxidant, anti-inflammatory and antiapoptotic activities (9). 
Many forms of chromium $(\mathrm{Cr})$ exist in nature; hexavalent $\mathrm{Cr}(\mathrm{Cr}(\mathrm{VI}))$ is the main form of $\mathrm{Cr}$ emitted as an environmental pollutant and toxin in automobile exhaust and cigarette smoke (10). Additionally, $\mathrm{Cr}(\mathrm{VI})$ is widely used in chemical industrial processes such as wood preservation, dye production, alloy manufacturing, leather tanning and electroplating (11).

Long-term environmental $\mathrm{Cr}(\mathrm{VI})$ exposure from pollution may lead serious damage to human health (12); accumulation of $\mathrm{Cr}(\mathrm{VI})$ in the human body can cause dermatitis, chronic bronchitis, cancer, asthma, DNA mutation, hypertension (13) and testicular damage (14).

$\mathrm{Cr}(\mathrm{VI})$ is a powerful oxidizing agent. Upon chronic or acute exposure through inhalation, skin contact or consumption in drinking water, $\mathrm{Cr}(\mathrm{VI})$ exhibits carcinogenicity, cytotoxicity, mutagenicity and genotoxicity in very important organs such as liver, lungs and kidneys (15). The kidney is the main route of excretion of heavy metals such as $\mathrm{Cr}(\mathrm{VI})$; these metals are deposited in renal tissue, where they cause damage to the proximal tubule (16-17) and increase reactive oxygen species (ROS) production, promoting cellular and genomic damage and ultimately resulting in free radical-induced apoptosis in renal tissue (18-19).

There is much evidence to suggest that ROS over-production due to intracellular reduction of $\mathrm{Cr}(\mathrm{VI})$ leads to a high degree of instability and the presence of reactive $\mathrm{Cr}(\mathrm{III}), \mathrm{Cr}(\mathrm{IV})$ and $\mathrm{Cr}(\mathrm{V})$ species $(10,18,20)$.

Therefore, this study was carried out to investigate the nephroprotective effects of GSO against nephrotoxicity induced by $\mathrm{Cr}$.

\section{Materials and methods}

\section{Chemicals}

$\mathrm{Cr}(\mathrm{VI})$ was purchased from El Naser Pharmaceutical Chemicals Company, Cairo.

GSO was obtained from Haraz Egypt Company, Cairo, Egypt. Diagnostic kits for assaying serum urea, creatinine, and glucose were purchased from Biodiagnostic Company. Diagnostic kits used for determination of serum levels of sodium and potassium were purchased from Sensa Core Electrolyte, India. Diagnostic kits for assaying lipid peroxidation (as malondialdehyde, MDA)
(Cat. No. MD 25 29), reduced glutathione (GSH) (Cat. No. GR 2511 ) and catalase (CAT) (Cat. No. CA 25 17) activity in renal tissue were purchased from Biodiagnostic Company.

\section{Animals}

Forty male albino rats (140-160 g) were obtained from the Al-Zyade Experimental Animal Production Center, Giza, Egypt, assigned to 4 experimental groups of 10 rats each. The rats were housed in polypropylene cages at the animal facility of the Faculty of Veterinary Medicine, University of Sadat City, Egypt and were maintained under conditions of $22{ }^{\circ} \mathrm{C}$ and $55 \%$ humidity with a $12 \mathrm{~h}$ light/ $12 \mathrm{~h}$ dark cycle. They were supplied with a balanced diet and clean water ad libitum. Before the experiment began, the animals were placed under observation for a two-week acclimatization. All procedures were approved by the Animal Care Committee of University of Sadat City (Approval number: VUSC-022-5-19).

\section{Experimental design}

Forty male albino rats were assigned into 4 groups of 10 rats each. The experiment was conducted once.

Group I (control group). The rats were supplied with a balanced diet and clean water ad libitum

Group II (Cr(VI))-intoxicated group). The rats were given potassium dichromate in drinking water for 12 weeks at a concentration of 1000 $\mathrm{mg} / \mathrm{L}$ (353.5 mg/L Cr(VI)) (21).

Group III (GSO-treated group). The rats were administered GSO at a dose of $3.7 \mathrm{~g} / \mathrm{kg}$ body weight/day orally for 12 weeks (7).

Group IV (Cr(VI)) \& GSO-treated group). The rats were administered GSO at a dose of $3.7 \mathrm{~g} / \mathrm{kg}$ body weight/day orally together with potassium dichromate in drinking water at a concentration of $1000 \mathrm{mg} / \mathrm{L}$ (353.5 mg/L Cr(VI) for 12 weeks.

\section{Sampling}

At the end of the experimental period (12 weeks), the animals were subjected to $12 \mathrm{~h}$ of fasting. Then, after the animals were anaesthetized with diethyl ether ( $\geq 99.0 \%$; Sigma Aldrich), blood samples were withdrawn from the medial canthus of the eyes with capillary tubes. The blood samples were collected 
in glass tubes without anticoagulant, allowed to clot, and centrifuged for $10 \mathrm{~min}$ at $3000 \mathrm{xg}$. The collected serum samples were kept at $-80{ }^{\circ} \mathrm{C}$ until they were used for biochemical assays. Then, the rats were sacrificed by cervical dislocation, and the kidneys were immediately excised and washed with $0.9 \% \mathrm{NaCl}$. Each kidney sample was divided into 3 parts. The first part was stored at $-80{ }^{\circ} \mathrm{C}$ for lipid peroxidation (MDA) measurment and antioxidant defence system (GSH, CAT) assays. The second part was kept in PBS for genotoxicity investigation and was used to examine the rate of DNA damage (by comet assay). The third part of the kidney tissue was placed in 10\% neutral buffered formalin for histopathological examination using haematoxylin and eosin (H\&E) staining.

\section{Biochemical analysis}

Renal tissue homogenate was prepared according to the methods of Shawky et al. (22). Specific diagnostic kits were used to determine the serum levels of urea according to the methods of Fawcett and Scott (23). Specific diagnostic kits for determination of serum levels of creatinine were purchased from Diamond Diagnostics Inc. and were used according to the methods of Bartles et al. (24). Serum glucose was assayed using a Spinreact kit according to the methods of Trinder (25). Serum levels of sodium and potassium were determined according to the methods of El-Masry et al. (26).

Lipid peroxidation (MDA) was determined using a commercial kit from Biodiagnostic Company according to the procedure described by Ohkawa et al. (27). GSH content was determined in kidney homogenate according to the procedure described by Beutler et al. (28). CAT activity was determined in renal tissue homogenate according to the procedure described by Aebi (29).

\section{Histopathological examination}

Kidney tissue samples intended for histopathological investigation were fixed in $10 \%$ neutral formalin. The samples were prepared according to the methods of Bancroft et al. (30) and stained with H\&E (31).

Genotoxicity assays (single-cell gel

electrophoresis or comet assays)

Slides were prepared according to the methods described by Klaude et al. (32) and Orabi et al. (33). The fluorescent stain was visualized (at 400×magnification) using an automated fluorescence microscope, and images were captured on a computer equipped with Comet Score software (Komet IV). Three parameters were adopted as indicators of DNA damage: tail length (TL; length of DNA migration), comet tail DNA percentage (tail DNA\%) and tail moment (TM) (34).

\section{Statistical analysis}

Statistical analysis of the obtained results was performed using analysis of variance (ANOVA) with SPSS software (SPSS version 13.0, IBM, Chicago, IL, USA).

Post-hoc Duncan Differences with values of $p$ $<0.05$ were regarded as statistically significant. The results are expressed as the mean \pm standard error of the mean (SEM).

\section{Results}

\section{Biochemical tests}

The serum urea, creatinine, glucose and potassium levels were significantly elevated $(\mathrm{p}<0.05)$ in the oral Cr-treated animals compared to the control animals, while the serum sodium levels were decreased. GSO administration in combination with $\mathrm{Cr}$ promoted significant decreases $(p<0.05)$ in the serum levels of urea, creatinine, potassium and glucose compared to Cr treatment alone (Table 1).

\section{Levels of MDA, GSH and CAT in rat renal tissue}

As shown in Table 2, the levels of MDA were significantly elevated in the Cr-intoxicated group compared to the control group, whereas the activity of the antioxidant enzymes GSH and CAT was significantly decreased $(p<0.05)$. GSO treatment in combination with $\mathrm{Cr}$ significantly ameliorated $(\mathrm{p}<0.05)$ the changes in the levels of MDA and the activity of the antioxidant enzymes 
Table 1: Effects of $\mathrm{Cr}(\mathrm{VI})$ and/or GSO on the levels of serum kidney function markers, electrolytes and glucose

\begin{tabular}{lcccc}
\hline & Control & $\mathrm{Cr}(\mathrm{VI})$ & GSO & Cr(VI)+ GSO \\
\hline Urea $(\mathrm{mmol} / \mathrm{L})$ & $13.66 \pm 0.66^{\mathrm{c}}$ & $23.42 \pm 1.07^{\mathrm{a}}$ & $13.48 \pm 0.39^{\mathrm{c}}$ & $15.64 \pm 0.64^{\mathrm{b}}$ \\
Creatinine $(\mu \mathrm{mol} / \mathrm{L})$ & $69.84 \pm 0.88^{\mathrm{bc}}$ & $87.52 \pm 1.77^{\mathrm{a}}$ & $68.07 \pm 1.77^{\mathrm{c}}$ & $72.49 \pm 0.88^{\mathrm{b}}$ \\
$\mathrm{Na}+(\mathrm{mmol} / \mathrm{L})$ & $145.6 \pm 0.86^{\mathrm{a}}$ & $138.8 \pm 1.05^{\mathrm{b}}$ & $143.7 \pm 0.49^{\mathrm{a}}$ & $143.0 \pm 0.77^{\mathrm{a}}$ \\
$\mathrm{K}^{+}(\mathrm{mmoI} / \mathrm{L})$ & $4.85 \pm 0.089^{\mathrm{b}}$ & $5.55 \pm 0.11^{\mathrm{a}}$ & $4.69 \pm 0.12^{\mathrm{b}}$ & $4.88 \pm 0.065^{\mathrm{b}}$ \\
Glucose $(\mathrm{mmol} / \mathrm{L})$ & $5.86 \pm 0.23^{\mathrm{b}}$ & $6.89 \pm 0.35^{\mathrm{a}}$ & $5.89 \pm 0.18^{\mathrm{b}}$ & $5.96 \pm .12^{\mathrm{b}}$ \\
\hline
\end{tabular}

The values are expressed as the mean \pm SEM; number of rats $=10$.

Values carrying different letters in the same row are significantly different. , $\mathrm{p}<0.05$.

Table 2: Effects of $\mathrm{Cr}(\mathrm{VI})$ and/or GSO on the levels of MDA, GSH and CAT in renal tissue

\begin{tabular}{lcccc}
\hline & Control & Cr(VI) & GSO & Cr(VI)+ GSO \\
\hline MDA (nmol/g) & $168.9 \pm 4.62^{\mathrm{b}}$ & $222.2 \pm 18.7^{\mathrm{a}}$ & $167.2 \pm 6.54^{\mathrm{b}}$ & $157.8 \pm 3.93^{\mathrm{b}}$ \\
GSH (mmol/g) & $1.67 \pm 0.089^{\mathrm{a}}$ & $1.35 \pm 0.037^{\mathrm{b}}$ & $1.73 \pm 0.096^{\mathrm{a}}$ & $1.66 \pm 0.106^{\mathrm{a}}$ \\
CAT (U/g) & $4.19 \pm 0.06^{\mathrm{a}}$ & $2.30 \pm 0.25^{\mathrm{b}}$ & $4.07 \pm 0.01^{\mathrm{a}}$ & $4.32 \pm 0.04^{\mathrm{a}}$ \\
\hline
\end{tabular}

The values are expressed as the mean $\pm \mathrm{SE}$; number of rats $=10$.

Values carrying different letters in the same row are significantly different, $\mathrm{p}<0.05$.

Table 3: Evaluation of DNA damage in the kidney tissue of the $\mathrm{Cr}(\mathrm{VI})$ and/or GSO-treated rats (Comet assay)

\begin{tabular}{lcccr}
\hline & Control & Cr(VI) & GSO & Cr(VI)+ GSO \\
\hline Tail length $(\mu \mathrm{m})$ & $0.52 \pm 0.1^{\mathrm{b}}$ & $4.68 \pm 1.35^{\mathrm{a}}$ & $0.54 \pm 0.31^{\mathrm{b}}$ & $1.80 \pm 0.31^{\mathrm{b}}$ \\
Tail DNA\% & $1.97 \pm 0.75^{\mathrm{b}}$ & $12.19 \pm 1.27^{\mathrm{a}}$ & $1.81 \pm 0.51^{\mathrm{b}}$ & $6.19 \pm 1.7^{\mathrm{b}}$ \\
Tail moment & $0.01 \pm 0.001^{\mathrm{b}}$ & $0.57 \pm 0.02^{\mathrm{a}}$ & $0.01 \pm 0.001^{\mathrm{b}}$ & $0.12 \pm 0.005^{\mathrm{b}}$ \\
\hline
\end{tabular}

The values are expressed as the mean $\pm \mathrm{SE}$; number of rats $=10$.

Values carrying different letters in the same row are significantly different, $\mathrm{p}<0.05$.
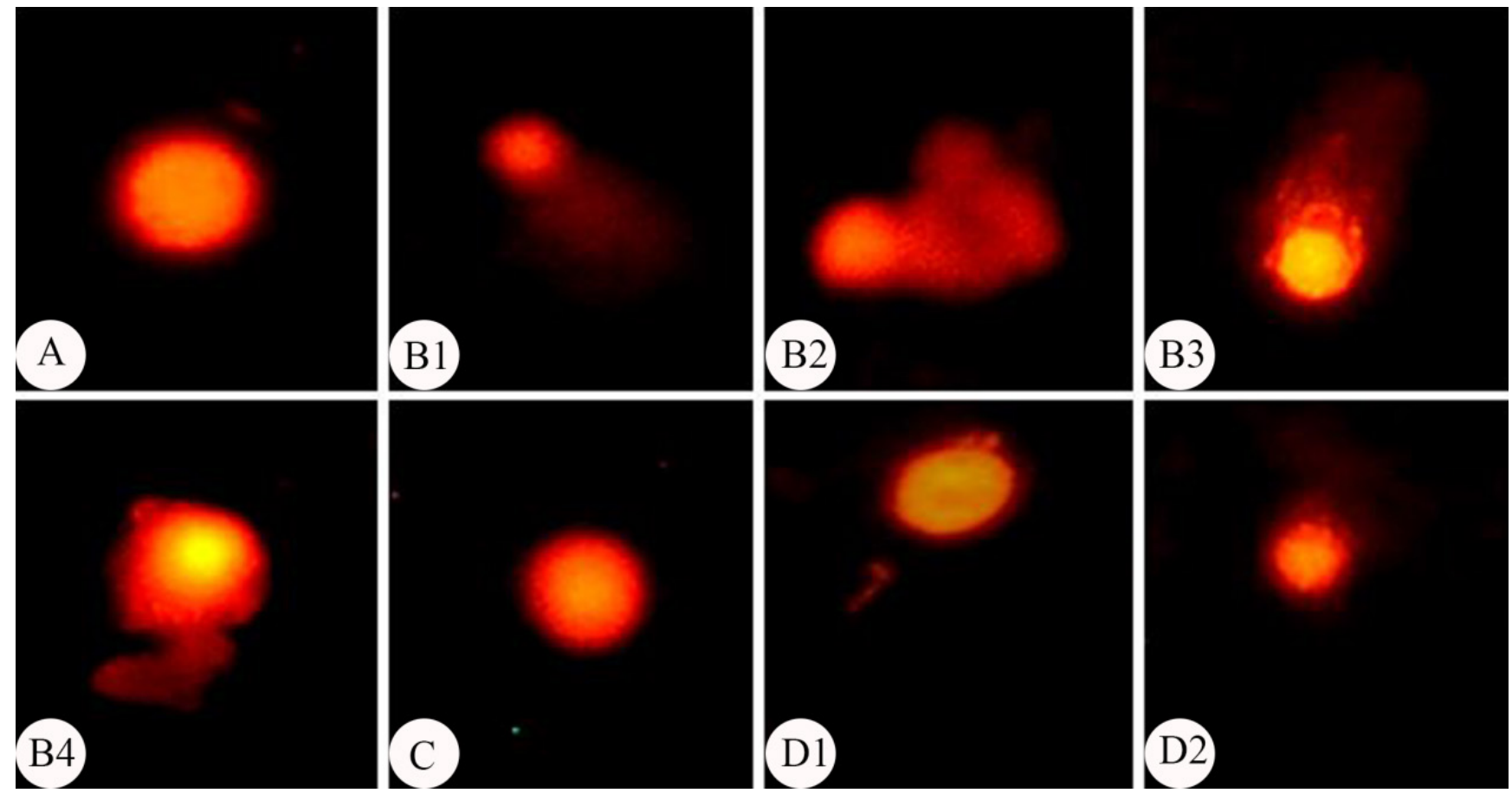

Figure 1: Comet assay for evaluation of renal tissues DNA damage: A, Control group; B (1-4), Cr VI intoxicated; C, GSO group; D, Cr VI + GSO group 
Figure 2: Photomicrographs of the kidney transverse sections stained with H\&E in different groups. A\&C kidney sections of control (GI) and GSO treated group (GIII) showing normal histological structure of renal corpuscles and renal tubules (H\&E X 200). B: kidney sections of rat kidneys of $\mathrm{Cr}$ (VI) intoxication group (GII) showing focal area of fibrosis of cortical interstitial tissue. (H\&E X 400). Kidney sections of GSO\& Cr VI administrated group showing mild degeneration of lining epithelium with karyopyknosis of some renal tubules in cortical area. (H\&E X400)

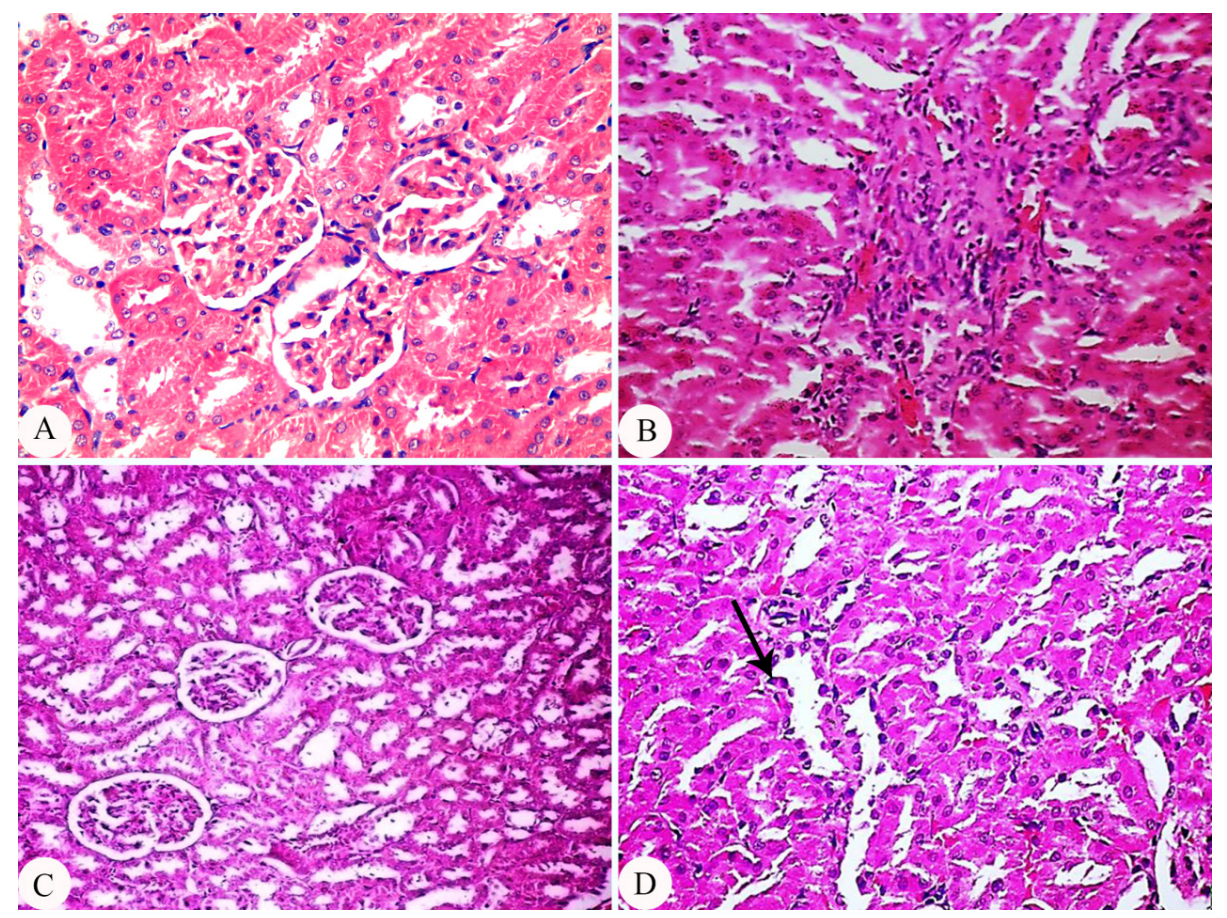

GSH and CAT caused by $\mathrm{Cr}$ alone.

DNA damage in rat renal tissue

A comet assay was performed to assess the protective effects of GSO against $\mathrm{Cr}$-induced DNA damage in renal tissue of rats. $\mathrm{Cr}$ induced DNA damage in rats, as indicated by increases in TL, tail DNA\% and TM in group II compared with the control group. Administration of GSO to $\mathrm{Cr}$ intoxicated rats (in group IV) protected DNA from damage. On the other hand, administration of GSO alone (in group III) had no significant effect on renal tissue DNA as shown in Table 3 and Fig. 1.

\section{Histological structure of rat renal tissue}

Fig. 2 illustrates the histological changes in the renal tissue of the control and treated groups. Histopathological examination of the renal tissue of the control and GSO groups showed normal histological structures of the renal corpuscles and renal tubules (Fig.2A, 2C) while histopathological examination of the renal tissue of $\mathrm{Cr}$ intoxicated group showed marked necrosis of the renal tubular epithelium lining with fibrosis of interstitial tissue in the cortex and medulla (Fig. 2B). Administration of GSO to Cr-intoxicated rats (in group IV) protected the structure of renal tissues from damage and showed mild degenerative changes in the renal tubular epithelium lining (Fig.2D).

\section{Discussion}

Environmental exposure to $\mathrm{Cr}$ associated with stainless steel industrial processes, spray paints, drinking water, chrome plating, photography and metallurgy is well known to cause renal injury in animals and humans (15). Previous studies have suggested that $\mathrm{Cr}(\mathrm{VI})$ induces generation of ROS and thereby induces oxidative stress and apoptosis (35). Therefore, supplementation of $\mathrm{Cr}-$ intoxicated animals and humans with natural antioxidants may be healthful. GSO exhibits stronger antioxidant activity than vitamin $\mathrm{E}$, vitamin $C$ and $\beta$-carotene (36), enabling this substance to protect the kidney from contrastinduced nephrotoxicity (37). The present results revealed that intoxication with $\mathrm{Cr}$ altered kidney function, as indicated by the increased serum levels of urea, creatinine, and potassium and decreased serum levels of sodium in Cr-treated rats, which might have been due to renal tissue injury induced by $\mathrm{Cr}(\mathrm{VI})$. These findings are consistent with those of Abdel-Rahman et al. (38), who reported that administration of $\mathrm{Cr}(\mathrm{VI})$ significantly increased serum levels of urea and creatinine while simultaneously causing weight gain and pathological alterations in the kidney. The elevated levels of serum urea and creatinine 
may have been due to toxic injury to the tubules induced by potassium dichromate. Additionally, Sahu et al. (39) demonstrated that a single injection of potassium dichromate resulted in significant increases in the serum levels of urea and creatinine that were linked to oxidative stress, inflammation and apoptosis accompanied by histopathological changes in renal tissues. Cotreatment with GSO significantly attenuated the elevations in serum urea and creatinine observed in $\mathrm{Cr}(\mathrm{VI})$-administered rats. In the present study, the decreased levels of the antioxidants GSH and CAT and the increased levels of MDA in $\mathrm{Cr}(\mathrm{VI})$-intoxicated rats indicated the presence of increased oxidative stress in the kidney. The decreased GSH levels may have been attributable to increased GSH consumption to neutralize $\mathrm{Cr}(\mathrm{VI})$-induced free radicals or to binding of a $\mathrm{SH}$ group to $\mathrm{Cr}(39)$. CAT is biologically necessary for the reduction of $\mathrm{H}_{2} \mathrm{O}_{2}$. In this study, the decline in the activity of CAT may have been due to intracellular accumulation of ROS, including $\mathrm{H}_{2} \mathrm{O}_{2}$ and superoxide anions, that overwhelmed the enzymatic activity (35). Cotreatment of $\mathrm{Cr}$ intoxicated rats with GSO preserved the activity of CAT and GSH, indicating that GSO prevented the toxic effects of $\mathrm{Cr}(\mathrm{VI})$ through its antioxidant properties.

ROS-mediated oxidative stress is known to attack DNA and cause DNA lesions. In this study, Histopathological alterations, such as fibrosis of cortical interstitial tissue in $\mathrm{Cr}(\mathrm{VI})$-administered rats were also considerably reduced in rats cotreated with GSO.These results were consistent with those of Song et al. (40) which recorded that exposure to $\mathrm{Cr}(\mathrm{VI})$, followed by a significant increase in tubular injury score in renal tissue .Furthermore, Mohamed et al. (41) reported that $\mathrm{Cr}$ (VI) induced various types of cell damage, inflammatory and vascular alterations in renal tissue

Renal tissue injury was related to renal tissue DNA damage, which was detected as increases in TL, tail DNA\% and TM. These effects may have resulted from $\mathrm{Cr}(\mathrm{VI})$-induced oxidative stress that subsequently damaged DNA. Sahu et al. (39) found that $\mathrm{Cr}$ induced DNA damage, renal oxidative stress, apoptosis, and inflammation in renal tissue. The renoprotective effect of GSO could be ascribed to its antioxidant effect. The antioxidant activity of the GSO is due to its high polyphenolic constituents such as resveratrol ,catechin, procyanidins, gallic acid, proanthocyanidins, and contents of vitamin E $(42,43,44)$. Resveratrol has potant antioxidant, anti-carcinogenic, and antiinflammatory activities that might be mediated by activation of silent information regulator protein 1 (SIRT1) gene expression (44) catechin, Procyanidins, and gallic acid were documented to be strong cellular preventive agents against oxidative DNA damage and apoptosis by induction of endogenous antioxidant enzymes (45), (46). Also GSO has played a key role in reducing oxidative stress and inhibiting the inflammatory responses. This could be due to the induction of antioxidant enzymes, the down-regulation of CYP2E 1 and the expression of the iNOS gene, and the control of the inflammatory process through the downregulation of NF-kB and activation of SIRT1 as well antiapototic effect mediated by down-regulation Caspase- 3 gene expression, in addition to the regulation of the trace metals levels in tissues (47). In addition, grape seed proanthocyanidins extract (GSPE) can improve the nephrotoxicity and DNA damage caused by cisplatin in rats treated with grape seed extract and fish oil (48). Also, GSPE exhibits scavenging of peroxyl and superoxide radicals that can protect the renal tissue against oxidative stress that causes damage to the renal tissue, apoptosis, and fragmentation of DNA (49, 50). Furthermore, treatment of Ehrlich solid tumor (EST) induced renal injury in mice with GSPE improved renal tissue structure and reduced renal tissue DNA damage and P53, PCNA and ki67 proteins expression (51).

GSO, with its strong antioxidant properties, ameliorated the DNA damage caused by $\mathrm{Cr}(\mathrm{VI})$ intoxication

We concluded that GSO is a promising nephroprotective agent against $\mathrm{Cr}(\mathrm{VI})$-induced nephrotoxicity

\section{Acknowledgement}

Authors declare that there is no conflict of interest.

\section{References}

1. Vislocky LM, Fernandez M L. Biomedical effects of grape products. Nutr Rev 2010; 68(11): 656-70.

2. Maier T, Schieber A, Kammerer DR, Carle R. 
Residues of grape (Vitis vinifera L.) seed oil production as a valuable source of phenolic antioxidants. Food Chem 2009; 112(3): 551-9.

3. Natella F, Belleli F, Gentili V, Ursini F, Scaccini C. Grape seed proanthocyanidins prevent plasma postprandial oxidative stress in humans. J Agric Food Chem 2002; 50(26): 7720-5.

4. Yu J, Ahmedna M. Functional components of grape pomace: their composition, biological properties and potential applications. Int $\mathrm{J}$ Food Sci Technol 2013; 48(2): 221-37.

5. Walle T, Hsieh F, DeLegge MH, Oatis JE, Walle UK. High absorption but very low bioavailability of oral resveratrol in humans. Drug Metab Dispos 2004; 32(12): 1377-82.

6. Bagchi D, Bagchi M, Stohs SJ, Ray SD, Sen CK, Preuss HG. Cellular protection with proanthocyanidins derived from grape seeds. Ann N Y Acad Sci 2002; 957(1): 260-70.

7. Maheswari MU, Rao PGM. Antihepatotoxic effect of grape seed oil in rat. Indian $\mathrm{J}$ Pharmacol 2005; 37(3): 179-82.

8. Bagchi D, Ra SD, Bagchi M, Preuss HG, Stohs, SJ. Mechanistic pathways of antioxidant cytoprotection by a novel IH636 grape seed proanthocyanidin extract. Indian J Exp Biol 2002; 40(6): 717-26

9. Ismail AF, Salem AA, Eassawy MM. Hepatoprotective effect of grape seed oil against carbon tetrachloride induced oxidative stress in liver of $\gamma$-irradiated rat. $\mathrm{J}$ Photochem Photobiol B 2016; 160: e1-10. doi: 10.1016/j.jphotobiol.2016.03.027

10. Wu F, Sun H, Kluz T, Clancy H A, Kiok K, Costa M. Epigallocatechin-3-gallate (EGCG) protects against chromate-induced toxicity in vitro. Toxicol Appl Pharmacol 2012; 258(2): 166-75.

11. Mishra S, Bharagava RN. Toxic and genotoxic effects of hexavalent chromium in environment and its bioremediation strategies $\mathrm{J}$ Environ Sci Health C Environ Carcinog Ecotoxicol Rev 2016; 34(1): 1-32.

12. Fernández PM, Vinarta SC, Bernal AR, Cruz EL, Figueroa LI. Bioremediation strategies for chromium removal: current research, scale-up approach and future perspectives. Chemosphere 2018; 208: 139-48.

13. Junaid M, Hashmi MZ, Malik RN, Pei DS. Toxicity and oxidative stress induced by chromium in workers exposed from different occupational settings around the globe: a review. Environ Sci Pollut Res Int 2016; 23(20): 20151-67.
14. Marouani N, Tebourbi O, Hallegue D, et al. Mechanisms of chromium hexavalent-induced apoptosis in rat testes. Toxicol Ind Health 2017; 33(2): 97-106.

15. Khan MR, Siddiqui S, Parveen K, Javed S, Diwakar S, Siddiqui WA. Nephroprotective action of tocotrienol-rich fraction (TRF) from palm oil against potassium dichromate (K2Cr2O7)-induced acute renal injury in rats. Chem Biol Interact $2010 ; 186(2): 228-38$.

16. Yam Canul P, Chirino Y I, Sánchez González DJ, Martínez Martínez C M, Cruz C, Pedraza Chaverri J. PJ34, a poly adenosine diphosphate ribose polymerase inhibitor, attenuates chromate induced nephrotoxicity. Basic Clin Pharmacol Toxicol 2008; 102(5): 483-8.

17. Parveen K, Khan M R, Siddiqui WA. Pycnogenol ${ }^{\circledR}$ prevents potassium dichromate (K2Cr2O7)-induced oxidative damage and nephrotoxicity in rats. Chem Biol Interact 2009; 181(3): 343-50.

18. Pedraza-Chaverrí J, Barrera D, Medina-Campos ON, et al. Time course study of oxidative and nitrosative stress and antioxidant enzymes in $\mathrm{K} 2 \mathrm{Cr} 2 \mathrm{O}$ 7-induced nephrotoxicity. BMC Nephrol 2005; 6(1): e4. doi: 10.1186/14712369-6-4

19. Fatima S, Mahmood R. Vitamin C attenuates potassium dichromate-induced nephrotoxicity and alterations in renal brush border membrane enzymes and phosphate transport in rats. Clin Chim Acta 2007; 386(1/2): 94-9.

20. Molina-Jijón E, Zarco-Márquez G, Medina-Campos ON, et al. Deferoxamine pretreatment prevents $\mathrm{Cr}$ (VI)-induced nephrotoxicity and oxidant stress: role of $\mathrm{Cr}$ (VI) chelation. Toxicology 2012; 291(1/3): 93-101.

21. Elbetieha A, Al-Hamood M H. Long-term exposure of male and female mice to trivalent and hexavalent chromium compounds: effect on fertility. Toxicology 1997; 116(1/3): 39-47.

22. Shawky SM, Ramadan SG, Orabi, SH. Hemato-biochemical, behavioral and neurological effects of vitamin $\mathrm{C}$ administration against lead exposure in mice. Int $\mathrm{J}$ Adv Res 2014; 2: 418-29.

23. Fawcett J K, Scott J. A rapid and precise method for the determination of urea. Journal of clinical pathology.1960; 13(2): 156-9.

24. Bartels H, Böhmer M, Heierli C. Serum creatinine determination without protein precipitation. Clin Chim Acta 1972; 37: 193-7.

25. Trinder P. Determination of blood glucose 
using 4-amino phenazone as oxygen acceptor. J Clin Pathol 1969; 22(2): 246.

26. El-Masry TA, Al-Shaalan NH, Tousson E, El-Morshedy K, Al-Ghadeer A. P53 expression in response to equigan induced testicular injury and oxidative stress in male rat and the possible prophylactic effect of star anise extracts. Annu Res Rev Biol 2017; 14(1):1-8.

27. Ohkawa H, Ohishi N, Yagi K. Assay for lipid peroxides in animal tissues by thiobarbituric acid reaction. Anal Biochem 1979; 95(2): 351-8.

28. Beutler E. Improved method for the determination of blood glutathione. J Lab Clin Med 1963; 61: 882-8.

29. Aebi H. Catalase in vitro. Methods Enzymol 1984; 105: 121-6.

30. Bancroft JD, Steven A, Turner DR. Theory and practice of histological techniques. New York : Churchill Livingstone, 1996: 129.

31. 31. Harris HF. On the rapid conversion of haematoxylin into haematein in staining reactions. J Appl Microsc Lab Methods 1900; 3(3): 777-80.

32. Klaude M, Eriksson S, Nygren J, Ahnström G. The comet assay: mechanisms and technical considerations. Mutat Res 1996; 363(2): 89-6.

33. Orabi SH, Shawky SM, Wirtu G, Mansour DA, Abdelaziz SA, Elsabbagh HS. Ginkgo biloba mitigates aluminum induced neurotoxicity in rats. Int J Biochem Res Rev 2018; 24(4): 1-14.

34. Collins AR, Oscoz AA, Brunborg G, et al. The comet assay: topical issues. Mutagenesis 2008; 23(3): 143-51.

35. Kalayarasan S, Sriram N, Sureshkumar A, Sudhandiran G. Chromium (VI) induced oxidative stress and apoptosis is reduced by garlic and its derivative S-allylcysteine through the activation of Nrf2 in the hepatocytes of Wistar rats. J Appl Toxicol 2008; 28(7): 908-19.

36. Bagchi D, Garg A, Krohn RL, Bagchi M, Tran M X, Stohs, S J. Oxygen free radical scavenging abilities of vitamins $\mathrm{C}$ and $\mathrm{E}$, and a grape seed proanthocyanidin extract in vitro. Res Commun Mol Pathol Pharmacol 1997; 95(2): 179-89.

37. Gupta N, Goswami B, Mittal P. Effect of standard anthracycline based neoadjuvant chemotherapy on circulating levels of serum IL- 6 in patients of locally advanced carcinoma breast-a prospective study. Int J Surg 2012; 10(10): 63840.

38. Abdel-Rahman G H, Abdel-Hady E K, Al-Harbi MS. Protective role of melatonin against chromium-induced nephrotoxicity in male rabbits. Global Vet 2012; 9(2): 225-31.

39. Sahu BD, Koneru M, Bijargi SR, Kota A, Sistla R. Chromium-induced nephrotoxicity and ameliorative effect of carvedilol in rats: Involvement of oxidative stress, apoptosis and inflammation. Chem Biol Interact. 2014; 223: 69-79.

40. Song MF, Yang Y, Yi ZW, et al. Sema 3A as a biomarker of the activated mTOR pathway during hexavalent chromium-induced acute kidney injury. Toxicol Lett 2018; 299: 226-35.

41. Mohamed AAR, El-Houseiny W, El-Murr AE, Ebraheim LL, Ahmed AI, El-Hakim YM A. Effect of hexavalent chromium exposure on the liver and kidney tissues related to the expression of CYP450 and GST genes of Oreochromis niloticus fish: role of curcumin supplemented diet. Ecotoxicol Environ Saf 2020; 188: e109890. doi: 10.1016/j.ecoenv.2019.109890

42. Fernández-Mar MI, Mateos R, García-Parrilla MC, Puertas B, Cantos-Villar E. Bioactive compounds in wine: resveratrol, hydroxytyrosol and melatonin: a review. Food Chem 2012; 130(4): 797-813.

43. Rockenbach II, Jungfer E, Ritter C, et al. Characterization of flavan-3-ols in seeds of grape pomace by CE, HPLC-DAD-MSn and LC-ESI-FTICR-MS. Food Res Int 2012; 48(2): 848-55.

44. Davidov-Pardo G, McClements DJ. Nutraceutical delivery systems: resveratrol encapsulation in grape seed oil nanoemulsions formed by spontaneous emulsification. Food Chem 2015; 167: 205-12.

45. Du Y, Guo H, Lou H. Grape seed polyphenols protect cardiac cells from apoptosis via induction of endogenous antioxidant enzymes. J Agric Food Chem 2007; 55(5): 1695-701.

46. Morin B, Narbonne JF, Ribera D, Badouard C, Ravanat JL. Effect of dietary fat-soluble vitamins $\mathrm{A}$ and $\mathrm{E}$ and proanthocyanidin-rich extract from grape seeds on oxidative DNA damage in rats. Food Chem Toxicol 2008; 46(2): 787-96.

47. Ismail AF, Salem AA, Eassawy MM. Hepatoprotective effect of grape seed oil against carbon tetrachloride induced oxidative stress in liver of $\gamma$-irradiated rat. J Photochem Photobiol B 2016; 160: 1-10.

48. Hassan HA, Edrees GM, El-Gamel EM, El-sayed EA. Amelioration of cisplatin-induced nephrotoxicity by grape seed extract and fish oil is mediated by lowering oxidative stress and DNA damage. Cytotechnology 2014; 66(3): 419-29. 
49. LI SG, Ding YS, Qiang NIU, et al. Grape seed proanthocyanidin extract alleviates arsenic-induced oxidative reproductive toxicity in male mice. Biomed Environ Sci 2015; 28(4): 272-80.

50. Ulusoy S, Ozkan G, Yucesan FB, et al. Antiapoptotic and antioxidant effects of grape seed proanthocyanidin extract in preventing cyclospo- rine A-induced nephropathy. Nephrology 2012; 17(4): 372-9.

51. Abd Eldaim MAA, Tousson E, El Sayed I El, Abd El-Aleim A H, Elsharkawy H N. Grape seeds proanthocyanidin extract ameliorates Ehrlich solid tumor induced renal tissue and DNA damage in mice. Biom Pharmacother 2019; 115: e108908. doi: $10.1016 /$ j.biopha.2019.108908

\title{
BLAŽILNI UČINKI OLJA GROZDNIH PEŠK PRI TOKSIČNI OBREMENITVI LEDVIC TER VPLIV NA OKSIDATIVNI STRES PODGAN, POVZROČEN S KROMOM
}

\author{
S. Hassan Orabi, S. Mohamed Shawky
}

Povzetek: Študija je bila osredotočena na proučevanje zaščitnih učinkov olja grozdnih pešk (GSO) pri toksični obremenitvi ledvic, povzročeni s heksavalentnim kromom $(\mathrm{Cr}(\mathrm{VI}))$. Štirideset samcev podgan je bilo naključno razdeljenih vštiriskupine: skupina I -kontrolna skupina, skupina ll, ki je v pitni vodi 12 tednov prejemala 1000 mg/Lkalijevega dikromata (353,5 mg/L Cr(VI)), skupina III, ki je peroralno 12 tednov prejemala 3,7 g/kg telesne mase/dan GSO ter skupina IV, ki je 12 tednov prejemala GSO skupaj s kalijevim dikromatom. Cr(VI) je znatno zvišal serumske ravni sečnine, kreatinina, kalija in glukoze v serumu. Poleg tega je Cr(VI) zvišal raven MDA in povzročil poškodbe ledvičnega tkiva in poškodbe DNK. Po drugi strani je $\mathrm{Cr}(\mathrm{VI})$ znižal serumsko raven natrija in antioksidativnega obrambnega sistema, zmanjšal raven glutationske peroksidaze in katalaze. Dodajanje GSO poskusnim živalim je preprečilo zvišanje ravni sečnine v serumu, kreatinina, kalija, natrija in glukoze. Poleg tega je GSO izboljšal obrambni sistem antioksidantov ledvičnega tkiva. Zaradi svojega zdravilnega učinka je izboljšal zlasti oksidativni stres, poškodbe ledvičnega tkiva in DNK. Rezultati kažejo, daje GSO obetavno zaščitno sredstvo za ledvica pri toksični obremenitvi, povzročeni s Cr(VI).

Ključne besede: olje grozdnih pešk; heksavalentni krom; nefrotoksičnost; poškodba DNK 